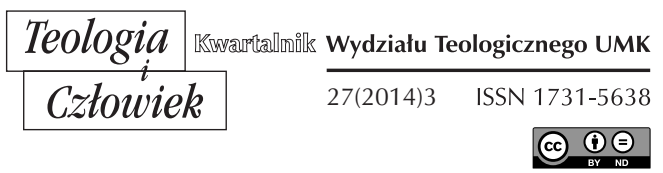

KS. WALDEMAR SZCZERBINSSKI*

GNIEZNO-POZNAŃ

\title{
CHARAKTERYSTYKA KULTURY ŻYDOWSKIEJ W IZRAELU I PRZEJAWY JEJ SEKULARYZACJI
}

DOI: http://dx.doi.org/10.12775/TiCz.2014.038

Izrael to nie tylko miejsce pielgrzymek ludzi z całego świata, lecz także stosunkowo młode państwo, którego obywatelami są Żydzi przybyli z całego świata i Arabowie będący muzułmanami lub chrześcijanami. Współczesny Izrael stał się sceną zarówno walki z zewnętrznym wrogiem (świat arabski), jak i wewnętrznej walki o charakter państwa, o tożsamość, której wyrazem jest żydowska kultura. Celem artykułu będzie próba scharakteryzowania kultury izraelskiej, a następnie ukazanie przejawów zeświecczenia tradycyjnej kultury żydowskiej w państwie żydowskim. Pozwoli to nam odpowiedzieć na kluczowe pytanie: czy i w jakim sensie izraelska kultura ma charakter żydowski?

Sekularyzacja (zeświecczenie) oznacza „proces społeczno-kulturowy, w wyniku którego różne dziedziny życia społecznego, jak: polityka, życie gospodarcze, nauka, filozofia, kultura, oświata, szkolnictwo, wychowanie, wyzwalają się stopniowo spod kontroli organizacji wyznaniowych, stają się niezależne od instytucji religijnych i kościelnych"1․ Współcześnie

* Ks. dr hab. Waldemar Szczerbiński, prof. UAM - jest kierownikiem Zakładu Kultury Judaizmu Instytutu Kultury Europejskiej UAM w Poznaniu.

${ }^{1}$ E. Chat, Religia w życiu czlowieka, Sandomierz 2009, s. 114-115. 
sekularyzm wiąże się raczej z pewnym typem mentalności naukowo-technicznej i racjonalistycznym sposobem myślenia, przedstawiającym obraz świata bez Boga, kwestionującym transcendentną wartość samego człowieczeństwa. W naukach społecznych termin "sekularyzacja” występuje w różnych znaczeniach: jako upadek lub zanik religii (instytucje religijne, dogmaty wiary i wartości religijne tracą swój dawny wpływ na społeczeństwo), jako przystosowanie się do świata (dotyczy grupy religijnej, która utworzyła się na religijnych podstawach, lecz w miarę upływu czasu zatraca swoją religijną odrębność), jako desakralizacja (odejście od religijnego rozumienia świata na rzecz logiczno-przyczynowego wyjaśniania zachodzących zjawisk), jako odłączenie społeczeństwa od religii (religia ogranicza się wówczas do życia prywatnego) ${ }^{2}$.

Erich Fromm dostrzegł, że "nie było takiej kultury w przeszłości - i jak się zdaje - nie może być takiej kultury w przyszłości, która by nie miała religii" ${ }^{3}$. Fenomen religijny stanowi zatem jeden $\mathrm{z}$ najbardziej powszechnych wyrazów ducha ludzkiego zarówno w sensie jednostkowym, jak i społecznym. Kultura jest przetwarzaniem natury, które pozostawia na niej ślad swoiście ludzki. W tym kontekście można powiedzieć, że religia dąży do czegoś więcej, do sakralizacji natury. „Religia jest dziedziną kultury, ale ją zarazem w swych tendencjach transcenduje. Zachodzi pewna odrębność porządku kultury jako porządku naturalnego (sfera aktywności człowieka) i porządku religii, który jest porządkiem wiary, przekraczającym porządek natury i znajdującym swe uzasadnienie nadprzyrodzone" ${ }^{\prime 4}$. Między postawą religijną człowieka, która dąży do sakralizacji, do uświęcenia świata, a sekularyzacją i desakralizacją staje rzeczywistość ziemska, życie doczesne z techniką, nauką i kulturą. Wartością dla religii jest świętość, która w żaden sposób nie pokrywa się $\mathrm{z}$ żadną inną wartością kultury (prawdą - w nauce, dobrem - w etyce, pięknem - w sztuce). Świętość jest wartością, która przenika inne wartości ludzkie ${ }^{5}$. W pierwotnym zamyśle Żydzi mieli być ludem świętym. Wydaje się zatem, że rozwój żydowskiej kultury pozbawionej wymia-

${ }^{2}$ Więcej na temat sekularyzacji zob. M. Radwan, Rodowód sekularyzacji, w: F. Adamski (red.), Socjologia religii. Wybór tekstów, Kraków 1983; P. Berger, The Sacred Canopy, New York 1967; W. Piwowarski (red.), Socjologia religii. Antologia tekstów, Kraków 1998; J. Baniak (red.), Sekularyzacja jako wyzwanie dla religii i Kościoła. Mity czy rzeczywistość, "Socjologia Religii” 4 (2006).

${ }^{3}$ E. Fromm, Szkice z psychologii religii, Warszawa 1968, s. 124.

${ }^{4}$ E. Chat, Religia, s. 46.

${ }_{5}$ Zob. Z. Zdybicka, Człowiek i religia, Lublin 1977, s. 317. 
ru religijnego traci swój historyczny sens. W Izraelu widać to bardzo wyraźnie.

Analiza kultury w Izraelu wymaga uprzedniego namysłu nad rozumieniem kultury żydowskiej jako takiej. Istotne dla naszych rozważań jest to, czy będziemy posługiwać się terminem „,kultura żydowska”, „,kultura judaizmu”, czy też "kultura izraelska”. Zbyt często spotykamy się bowiem z utożsamieniem pojęć: „żydowski”, ,judaistyczny”, izraelski”. Wydawać by się mogło, że w odniesieniu do rozumienia kultury jako humanizacji natury ${ }^{6}$ sprawa nie nastręcza większych trudności. Okazuje się jednak, że słowo „kultura” jest nieostre. John Storey za Raymondem Williamsem podkreśla, że kultura jest jednym z najbardziej wieloznacznych terminów $w$ języku angielskim ${ }^{7}$. Nie inaczej jest $w$ innych językach, w tym w języku polskim. Najczęściej terminu „kultura” używamy w jednym z trzech znaczeń. Po pierwsze, kultura może oznaczać określone procesy, zjawiska, nurty intelektualne, estetyczne czy duchowe. W tym sensie, mówiąc lub pisząc o kulturze w Izraelu, przywołujemy wybitne dzieła filozofów, malarzy, poetów stanowiące kanon izraelskiej sztuki, filozofii, literatury. Po drugie, słowo „kultura” odnosi się do stylów życia, wyznawanych systemów wartości jakichś grup ludzi w określonym czasie i przestrzeni. Kiedy opisuje się kulturę izraelską z tej perspektywy, uwaga zostaje skierowana nie tylko (czy niekoniecznie) na prądy intelektualne i estetyczne oraz ich głównych przedstawicieli, ale także na festiwale, imprezy sportowe, obchody świąt państwowych czy religijnych. Po trzecie, pojęcie kultury może być używane $\mathrm{w}$ znaczeniu pracy i praktyk intelektualnych oraz specyficznej artystycznej czy szerzej - performatywnej aktywności. Innymi słowy, kulturę traktuje się wówczas jako teksty i praktyki pełniące funkcję znaków (kodów) produkujących lub stwarzających okazję do tworzenia znaczeń. W tym ujęciu termin „kultura” jest bliski strukturalistycznemu i poststrukturalistycznemu konceptowi "znaczących praktyk” (signifying practices). Owe „znaczące praktyki” to np.: opera, balet, powieści. Pisząc o kulturze popularnej, odwołujemy się przede wszystkim do drugiego i trzeciego znaczenia pojęcia kultury. Tak rozumiana jako określone style życia i systemy wartości pozwala przyjrzeć się rozmaitym formom społecznej aktywności, takim jak: spędzanie wolnego czasu, robienie zakupów czy celebrowanie świąt. Z kolei trzecie

${ }^{6}$ Zob. E. Chat, Religia, s. 44.

7 J. Storey, Cultural Theory and Popular Culture. An Introduction, London 2009, s. $1-2$. 
ujęcie - kultura jako signifying practices - umożliwia analizę scenariuszy tzw. oper mydlanych, muzyki pop, komiksów jako przykładów kultury (popularnej).

Trudności pojawiają się jednak w zestawieniu kultury z "tym, co jest żydowskie". Kultura żydowska może być rozpatrywana podmiotowo lub przedmiotowo. Od strony podmiotowej kultura żydowska oznacza kulturę, którą tworzą Żydzi. Od strony przedmiotowej charakteryzuje ją to, że treściowo jest właśnie żydowska. Wyłaniają się jednak kolejne problemy. Nie jest łatwo określić, kogo uznać za Żyda i co stanowi o tym, że coś jest żydowskie. Odpowiedź zależy od tego, jakie zastosujemy kryterium. Na pojęcie „bycia Żydem” składają się różne kategorie, które są niezależne od siebie. Unterman wskazuje na cztery: „pochodzenie biologiczne, wyznanie, przynależność do wspólnoty kulturowej oraz przynależność etniczna lub państwowa i język, jakiego się używa"8. Niezależność tych kategorii powoduje, że o „żydowskości” mogą decydować wszystkie naraz kategorie, niektóre z nich lub tylko jedna z nich. Warto zwrócić uwagę, że w Izraelu poszczególne środowiska traktują te wyznaczniki w różny sposób. Motywy wyboru kryterium bywają różne. Pojęcie rasy można porzucić jako kryterium przyrodnicze. Posługiwanie się tym kryterium jest uprawnione w obrębie biologii pod warunkiem, że nie wyciąga się z ustalonych wniosków sądów wartościujących. Ponadto, faktem bezspornym jest wielorasowość Żydów, a treści myślenia nie są uwarunkowane biologicznymi odmianami występującymi wśród ludzi.

Kulturę, jako fenomen duchowy, trzeba pojmować w aspektach historycznych i wyjaśniać ją na podstawie warunków społecznych. Żydowskie środowisko i przyswojona tradycja, a nie rasowe pochodzenie, kształtują świadomość i mogą znaleźć wyraz także w kulturze. W czasach nowożytnych zaistniał problem dotyczący dwóch pozostałych kryteriów: czy Żydzi są wspólnotą narodową, czy religijną, czy też jedną i drugą? Na to pytanie sami Żydzi udzielają różnych odpowiedzi, w zależności od stopnia asymilacji w społeczeństwie, w którym żyją. Żydzi w starożytności i w średniowieczu stanowili grupę narodową i religijną zarazem i był to związek nierozerwalny także po ustaniu odrębnej państwowości żydowskiej. Nazwa „Żydzi” egzystowała równolegle z nazwami innych narodów, jak Grecy czy Egipcjanie. Mimo że żyli w rozproszeniu, utrzymywali swoją narodowość dzięki religii. Dopuszczali asymilację w stop-

\footnotetext{
${ }^{8}$ A. Unterman, Żydzi. Wiara i życie, Warszawa 2002, s. 19.
} 
niu nieszkodzącym integralności wspólnoty. Nigdy też nie porzucono nadziei na odzyskanie narodowej samodzielności, co stało się faktem po II wojnie światowej. W średniowiecznej chrześcijańskiej Europie pojęcie "Żyd" funkcjonowało obok pojęć „chrześcijanin" i „muzułmanin”. Przynależność religijną uznano za kryterium określające Żyda. Tak jak cechą charakterystyczną w starożytności była przynależność narodowa, tak w średniowieczu cechą tą była wyznawana religia. W późniejszym okresie, gdy Żydzi stawali się obywatelami poszczególnych narodów, czynnikiem wyróżniającym pozostało wyznawanie własnej religii. Pewnym wyjątkiem są wschodnioeuropejscy Żydzi, którzy stanowili odrębną wspólnotę kulturową, posługiwali się własnym językiem zwanym jidisz, a tożsamość wiązali $\mathrm{w}$ znacznym stopniu $\mathrm{z}$ aspektem narodowej niezależności. Obecnie przyznawanie się do religii żydowskiej (judaizm), jak i do narodu żydowskiego (syjonizm) jest wystarczającym kryterium klasyfikacji lub samookreślenia się Żyda. Jedność obu komponentów nie jest już rzeczą konieczną. Tak też jest w Izraelu. Język jako dodatkowy wyróżnik często nie był i nie jest związany z tym, co żydowskie. Kultura żydowska była oddzielona od arabskiej, pomimo posługiwania się przez sefardyjskich Żydów w starożytności językiem arabskim. W czasach nowożytnych Żydzi posługują się zazwyczaj językiem środowisk, w których zamieszkują. Kulturze żydowskiej brakuje więc językowej jednolitości, a jej dzieła są spisane w języku hebrajskim, jidisz, ladino oraz w języku kraju przebywania. Także w Izraelu nośnikiem kultury nie jest jedynie hebrajski, mimo że jest on oficjalny, preferowany i nauczany.

Kultury żydowskiej nie należy przeciwstawiać kultury jako takiej. Dookreślenie „żydowska” funkcjonowało w przeszłości w kontraście z filozofią chrześcijańską oraz muzułmańską i opierało się na kryterium religijnym. Średniowieczną kulturę żydowską cechowało bycie abstrakcyjnym przeciwieństwem kultury islamskiej i chrześcijańskiej. Nowożytna kultura żydowska nie zacieśnia się do religii, a judaizm pojmuje się często tylko jako przeszłe dziedzictwo, bez konotacji sakralnej. Stąd współcześnie tworzący Żyd nie jest już tożsamy z twórcą religijnym. Sprawę dodatkowo komplikuje fakt, że wielu żydowskich twórców identyfikuje się i utożsamia z kulturą krajów przebywania lub kulturą narodów, wśród których mieszkają. Powyższe rozważania prowadzą nas do postawienia kluczowego pytania: czy o żydowskości kultury decyduje jej podmiotowość, czy przedmiotowość? Czy kultura dlatego jest żydowska, że jej twórcą jest Żyd (podmiotowe podejście), czy też dlatego, że jej treść ma charakter żydowski, nawet jeśli autor nie jest Żydem (podejście przedmio- 
towe)? A może podmiot i przedmiot zarazem muszą być żydowskie? Jeśli jednak kryterium tego, co żydowskie, nie jest związane z judaizmem lub judaizm traktuje się jako kulturę, a nie religię, to co decyduje o żydowskości? Może rację ma Heschel, twierdząc, że „separacja wiary i wszelkiego działania, jak gdyby były one dwoma oddzielnymi przedziałami, może jedynie doprowadzić do schizofrenii judaizmu. Ponadto, mówienie o judaizmie jako o sposobie życia, gdzie wiara zajmuje drugie miejsce, jest uczynieniem niesprawiedliwości w stosunku do judaizmu" ${ }^{\prime \prime}$.

Przez całe tysiąclecia kultura żydowska miała charakter wybitnie religijny, co decydowało o jej wyjątkowości i specyfice. Można ją nazwać kulturą judaistyczną. Jednak od czasów oświecenia żydowskiego, w wyniku procesów asymilacyjnych, pojawiły się w niej elementy, które zrywały z ciągłością historyczną, wyznaczając nowe kryteria tożsamości żydowskiej. Judaizm rozumiany jako religia przestał być koniecznym wyznacznikiem żydowskości. Tym samym kultura żydowska jako kultura religijna, bądź też kultura związana z religią, przestała być jedyną i dominującą formą żydowskości. Od czasów Haskali nie tylko w granicach religijnych możliwa jest żydowska specyfika w sferze kultury. Tożsamość żydowska oparta na kryterium narodu znajduje ideologiczny wyraz w teorii politycznej, w ramach której znajduje się syjonizm. Ponieważ termin „kultura żydowska” nie implikuje już w sposób konieczny związku kultury z religią żydowską, uzasadnione jest mówienie o niej także w sytuacji, gdy takiego związku nie ma lub gdy przejawy kultury żydowskiej stoją nawet w wyraźnej sprzeczności z judaizmem. W dobie rugowania religii z szeroko rozumianej kultury religijna koncepcja kultury żydowskiej niejednokrotnie budzi sprzeciw. Próby dyskredytacji kultury związanej z religią płyną nie tylko z zewnątrz, ale także z wewnątrz danej grupy religijnej. Najczęściej powodem tego jest dostosowywanie się kultury czy samych twórców do przyjętych w danym czasie paradygmatów, rozumienia kultury oraz jej roli w społeczeństwie. Taka presja doprowadza coraz częściej do porzucenia jej istotnych wymiarów.

Jak widzimy, problem kultury żydowskiej zaczyna się już od rozumienia terminu „kultura”. Mówienie o totalnej separacji i neutralności światopoglądowej na terenie kultury wydaje się czystym anachronizmem i nie rozwiązuje problemu. Gdyby tak było, praktyki jej dookreślania byłyby niepotrzebne. Nie byłoby wówczas kultury arabskiej, żydowskiej,

${ }^{9}$ W. E. Kaufman (red.), Contemporary Jewish Philosophies, New York 1976, s. 6. 
chrześcijańskiej, ani nawet laickiej. Od czasu powstania państwa żydowskiego możemy mówić o kulturze izraelskiej, która jest przedmiotem naszych rozważań. W Izraelu przynależność do wspólnoty kulturowej nie jest też sprawą oczywistą. Życie każdej wspólnoty, także żydowskiej, zawiera elementy społeczne i kulturowe na równi z religijnymi. Powstaje pytanie, czy w Izraelu możemy mówić o wspólnocie kulturowej. Wydaje się, że uznając nawet jej istnienie, trzeba jasno stwierdzić, że jest ona niejednorodna, wręcz ogromnie zróżnicowana i stanowi wypadkową wielu kultur przybyłych do Izraela emigrantów, którzy musieli zmierzyć się z problemem asymilacji. Asymilacja to nie tylko zjawisko pozytywne. Proces ten wywołuje w sposób zamierzony lub niezamierzony także negatywne konsekwencje natury politycznej, religijnej, społecznej, ekonomicznej, religijnej, kulturowej, a nawet psychologicznej.

Sam termin "asymilacja” nie jest jasny i wciąż dyskutowany ${ }^{10}$. Todd Endelman zaproponował rozbicie tej kategorii na cztery wpływające na siebie, lecz odrębne procesy: akulturacja, integracja, emancypacja i sekularyzacja ${ }^{11}$. W kontekście asymilacji Żydów w Izraelu oznacza to, że przez akulturację rozumiemy przyjęcie kulturowych i społecznych zwyczajów dominującej grupy w Izraelu. Integrację rozumiemy jako wejście emigrantów żydowskich do izraelskich kręgów społecznych, gospodarczych i politycznych. Emancypacja oznacza otrzymanie przez emigrantów praw i przywilejów, jakie posiadają inni obywatele Izraela. Sekularyzacja to nic innego jak porzucenie tradycyjnych religijnych wierzeń (judaizmu jako takiego lub ortodoksji) oraz odejście od dotychczasowych praktyk religijnych. Akulturacja emigrantów żydowskich do Izraela może być postrzegana dwukierunkowo: od strony Izraelczyków (sabrów) jako zjawisko neutralne lub pozytywne, polegające na kulturowym upodobnieniu się do zastanej już społeczności izraelskiej - kierunek dośrodkowy; od strony emigrantów jako zjawisko negatywne, polegające na zakwestionowaniu i porzuceniu swojej dotychczasowej kultury - kierunek odśrodkowy. Jeśli akulturacja zakłada przyjęcie kultury dominującej grupy, to rodzi się pytanie, która z żydowskich grup w Izraelu jest ważniejsza lub dominująca. Trudno powiedzieć. Można odnieść wrażenie, że w państwie

${ }^{10}$ Szerzej na temat asymilacji zob. A. Jagodzińska, Asymilacja, czyli bezradność historyka. O krytyce terminu i pojęcia, w: K. Zieliński (red.), Wokót akulturacji i asymilacji Żydów na ziemiach polskich, Lublin 2010, s. 21.

${ }^{11}$ T. M. Endelman, Assimilation, w: G. D. Hundert (red.), The YIVO Encyclopedia of Jews in Eastern Europe, New Haven-London 2008, s. 81. 
żydowskim nie ma wspólnoty kulturowej i z tego powodu Izraelczycy czują się kulturowo zagubieni, a nawet wyobcowani.

Kultura w Izraelu nie jest tożsama z kulturą żydowską. Suwerenność polityczna Żydów wyłoniła problem tożsamości narodowej w nowych warunkach. „Nowa tożsamość nie powstaje w próżni [...]. Izrael to jest coś nowego, co powstaje w oparciu o coś bardzo starego i [...] nie jest to powrót tylko do tego, co było kiedyś, lecz także wysiłek wyzwolenia się z tego, co przeszkadzało Żydom w ciągu tych 2000 lat rozproszenia. Ten proces, choć politycznie zakończony, socjologicznie trwa nadal"12. Ta tożsamość będzie czymś innym niż tożsamość Żyda z diaspory oparta na kryterium religijnym, mianowicie nie będzie to tożsamość żydowska, lecz izraelska. Można powiedzieć, że jest ona jedynie częścią kultury żydowskiej na świecie związaną z określonym miejscem geograficznym. Izrael to wyjątkowa wielość światów skupionych na małej powierzchni, które są niejednorodne, sprzeczne, kontrastowe, a nawet skonfliktowane. Od czasów powstania państwa żydowskiego aż po dzień dzisiejszy mamy tu do czynienia z wielokulturowością. Izrael charakteryzuje się wielością postaw, poglądów i tożsamości Izraelczyków. Kategoria „Żyd w Izraelu" dotyczy:

nie tylko należących do ortodoksyjnego odłamu judaizmu pejsatych chasydów w czarnych kapotach i mitnagedów w garniturach, białych koszulach, czarnych kapeluszach, ale i Żydów, u których jedyną zewnętrzną oznaką żydowskości jest szydełkowa kipa. Żydami są modni dandysi z niepozorną kipą na głowie, nieróżniący się wiele w sposobie ubierania się czy w stylu życia od przeciętnego mieszkańca europejskiej metropolii, a także należący do narodu żydowskiego ateiści oraz Żydzi przestrzegający tradycji judaistycznej, chociaż nie wszystkich praw religijnych. Izraelczyk-Żyd pochodzący z Maroka czuje się o wiele bardziej związany z tym, który urodził się w Iraku czy Algierii, niż z Izraelczykiem-Żydem europejskim. Żyd świecki lepiej rozumie innego świeckiego Izraelczyka niż Żyda ultraortodoksyjnego. Z kolei ultraortodoksyjnym Żydom europejskim, odseparowanym od laickiego społeczeństwa, podzielonym na dwory chasydzkie i zwolenników różnych rabinów oraz przeciwstawiającym się im mitnagedów, trudno znaleźć wspólny język z przedstawicielami ortodoksyjnych Żydów pochodzących spoza Europy ${ }^{13}$.

12 I. Jaruzelska, Gdy czytam Biblię w Izraelu, Poznań 2002, s. 87.

${ }^{13}$ E. Sidi, Izrael oswojony, Warszawa 2013, s. 23. 
Przy takiej różnorodności i rozbieżności trudno określić, jaka grupa jest dominująca, właściwsza, prawdziwa, wzorcowa czy istotniejsza. Emigrant żydowski o określonej tożsamości ma poważny dylemat już w momencie przybycia do Izraela. Oczekuje się od niego, aby stał się Izraelczykiem. Ale co to znaczy? Bardzo trudno emigrantowi dostrzec to, co łączy Izraelczyków. Bardziej widoczne są różnice.

Bo co wspólnego ma ze sobą żydowski pasterz kóz z Jemenu z żydowskim urzędnikiem z Polski? Jak może dogadać się kramarz z Maroka z karczmarzem z Ukrainy? O czym może rozmawiać niepiśmienny Żyd z Etiopii z oczytanym w europejskich filozofach Żydem z Niemiec? O niczym. Bo nic ich nie łączy, a wszystko dzieli. Nawet kolor skóry. Lecz są także różnice głębsze, siedzące na dnie duszy, różnice tak wielkie, że nie wiadomo, która z tych dusz jest bardziej żydowska. Przecież ci z Polski jechali do Izraela budować nowy kraj. Żydzi z krajów arabskich wracali do ziemi przyrzeczonej przez Boga. Ci z Europy mieli wykutą na pamięć wielką ideę świeckiego, demokratycznego państwa, budowaną przez dziesięciolecia w politycznych sporach i debatach, opisaną na stronach gazet warszawskich czy wiedeńskich i w płomiennych syjonistycznych manifestach, drukowanych gotycką czcionką. Uchodźcy z Jemenu czy z Maroka słuchali tylko słów rabina, a rabin mówił, że żydowskie państwo nastanie, gdy nadejdzie oczekiwany Mesjasz. Ci z Europy byli wykształceni i światli, choć często dobrowolnie szli do pracy na roli. Ci z Maghrebu, z Azji i Afryki nie znali nawet liter. Aszkenazyjczycy stworzyli izraelską elitę, zostali premierami, dyrektorami, generałami. Sefardyjczyków nazwano czarnymi, nie tylko od karnacji skóry. Elita miała władzę; nie odda jej przez pierwsze dekady niepodległości. Czarni sprzątali aszkenazyjskie urzędy, ich kobiety pomagały europejskim paniom podawać do europejskich stołów. Tak było kiedyś. Dziś Sefardyjczycy mają większość w parlamencie. I co z tego, skoro symbolem elity jest nadal biały aszkenazyjczyk [...]. A na to wszystko nałożyła się alija rosyjska. Milion świeżych imigrantów: wspaniali filharmonicy, reżyserzy i aktorzy, ale też pijacy i narkomani, posowieccy urzędnicy, bandyci i ojcowie mafii. Zasiedlili całe miasteczka, zapisali cyrylicą dziesiątki ulicznych szyldów, niektórzy pracują na kilku etatach, inni wyciągają rękę po datki ${ }^{14}$.

Izrael nie jest łatwym krajem dla emigrantów, a procesy asymilacyjne są niezwykle złożone. Dlaczego?

${ }^{14}$ P. Smoleński, Izrael już nie frunie, Wołowiec 2011, s. 52-53. 
Izraelczyków określają różnice, nie podobieństwa - to część ich specyfiki - a komponentem scalającym jest żydowskość w sensie etnicznym i historyczno-kulturowym, choć niekoniecznie religijnym [...]. W Izraelu Żydzi już nie muszą solidarnie jednoczyć się $\mathrm{w}$ jednej wierze - mogą pozwolić sobie na świeckość bez uszczerbku na honorze i posądzenia o etniczną zdradę. W diasporze odwrócenie się od żydowskich korzeni mogło być uznawane za konformizm, "przejście na drugą stronę”. W Izraelu, „wśród swoich”, można sobie pozwolić na krytycyzm wobec judaizmu i Żydów. Można być Żydem kosmopolitą, świeckim przywiązanym do tradycji albo ortodoksyjnym - ma się wybór ${ }^{15}$.

Okazuje się, że Izraelczycy nie są monolitem, lecz zlepkiem żydowskich grup, które wywodzą się z wielu kultur i tradycji, które są podzielone z powodu języka, wyglądu i poglądów. Każda z tych izraelskich społeczności „stara się wytresować Medinat Israel według własnego modelu. I nikomu się to nie udaje. Izrael zraniony, nieufny i gotowy na wszystko, staje dęba, gryzie każdą uwięź i nie pozwala się ujeździć. To raczej on tresuje, niż jest tresowany"16. Po przyjeździe do Izraela Żydzi z różnych krajów i z różnych kultur musieli podjąć próbę zadomowienia się. Paradoksalnie było to zadanie o wiele trudniejsze, niż się spodziewali. Wiedzieli, że muszą się przystosować. Nie wiedzieli jednak, w jaki sposób. Na czym ma polegać akulturacja w Izraelu? Do czego lub do kogo ma się przystosować czy upodobnić przybyły do tego kraju emigrant? Jaki jest kulturowy wzorzec Izraelczyka? Czy ten określony przez przywódców syjonistycznych, czy może bardziej proponowany przez religijnych rabinów? Realia Izraela pokazują, że

wiara, religia żydowska, państwo Izrael i polityka to odrębne kategorie, a problem dychotomii chilonim i charedim nie istnieje, ponieważ „nie ma jednej, właściwej formuły judaistycznej”. Ten, kto z pieczołowitością dba o najmniejszy detal swojego ubrania, codziennie wypełnia nakazy rabinów czy chodzi do synagogi [...] wcale nie jest lepszym Żydem od tego, kto zdecydował, że żydowskość w jego życiu ograniczać się będzie do pójścia raz w roku do synagogi. „Nie ma jednego wyznacznika żydowskości i jednego typu Żyda"17.

\footnotetext{
15 E. Sidi, Izrael, s. 160-161.

16 Tamże, s. 10.

17 Tamże, s. 453.
} 
Stąd nie ma jednej kultury żydowskiej w Izraelu. Kultura izraelska to zlepek różnych kultur, z których żadna nie jest dominująca. Może w takiej sytuacji lepiej mówić o „kulturze Izraelczyków” lub „kulturze dla Izraelczyków” niż o „kulturze izraelskiej”"18, z wyłączeniem oczywiście nieżydowskich obywateli.

Wydaje się, że przedwojenna emigracja była $\mathrm{w}$ lepszej sytuacji przynajmniej z trzech powodów. Po pierwsze, jej przedstawiciele byli syjonistami - ludźmi ideowymi, którym przyświecał jasny cel wskrzeszenia państwa żydowskiego. Po drugie, syjonizm jasno określił ideał Izraelczyka, który miał się zrealizować w każdym żydowskim emigrancie. Po trzecie, przyjazd do Palestyny był nie tylko ich wolną decyzją, ale wręcz pragnieniem. Byli to zazwyczaj młodzi Żydzi o poglądach lewicowych, którym życie w tradycyjnej polskiej diasporze zupełnie nie odpowiadało. Syjonizm wydawał się im lepszą propozycją i wytyczał świetlaną przyszłość. Ben Gurion uważał, „że w każdym Żydzie tkwi i syjonista, i asymilant. Walka między nimi, powiedział, to najpilniejsza narodowa kwestia moralna stojąca w tej chwili przed Żydami"19. Syjonistyczna izraelskość, która wyrosła w zaprzeczeniu ciągłości historycznej i tradycji żydowskiej diaspory, „wytworzyła nowy typ Żyda-Izraelczyka opisanego przez brytyjskiego historyka Isaaka Deutschera jako non-Jewish-Jew, «nieżydowski Żyd», którego ojczyzną stał się Izrael"20. Syjonistyczna wizja mówiła o „nowym Żydzie” w nowym społeczeństwie, który przybędzie do Ziemi Izraela w poszukiwaniu osobistego i narodowego zbawienia. David Ben Gurion w roku 1944 stwierdził: „Naszej drogi nie określają ani nasze początki, ani nasza przeszłość, lecz nasza misja i nasza przyszłość" 21 . Takie było założenie syjonistów, które wyznaczało emigrantom kierunek asymilacji w państwie żydowskim. Izraelczyk miał stać się nowym rodzajem Żyda.

Przywódcy jiszuwu pragnęli zbudować nowy naród, oderwany od trwającej dwa tysiąclecia, pełnej ucisku historii Żydów na wygnaniu. Nowy człowiek, którego syjonizm chciał stworzyć, powinien być przeciwieństwem prześladowanego, pokornego starego Żyda, zarabiającego

${ }^{18}$ Podobne rozróżnienie w stosunku do pewnej grupy Żydów zaproponowała w kontekście sztuki M. Stolarska-Fronia, w: Udziat środowisk Żydów wroctawskich w artystycznym i kulturalnym życiu miasta od emancypacji do 1933 roku, Warszawa 2008, s. 16.

19 T. Segev, Siódmy milion, Warszawa 2012, s. 30.

${ }^{20}$ E. Sidi, Izrael, s. 161.

${ }^{21}$ B. L. Sherwin, Duchowe dziedzictwo Żydów polskich, Warszawa 1995, s. 232. 
na życie handlem i rzemiosłem. Nowe społeczeństwo syjonistyczne miało reprezentować twórczy, socjalistyczny, świecki postęp, uczyć dzieci dumy z niepodległości i umiejętności bronienia siebie i honoru. Jednak rzeczywistość komplikowała także ten syjonistyczny ideał: nowemu człowiekowi brakowało głębi; nie miał przeszłości, żadnych więzów z żydowską historią i żadnych powiązań z doświadczeniem większości Izraelczyków ${ }^{22}$.

Z założenia nie chodziło o zbudowanie państwa żydowskiego na wzór jakiegokolwiek państwa w Europie, w tym Polski. Przeciwnie, takie nastawienie emigrantów było tłamszone i źle widziane. Jak wynika z powyższych słów, emigranci żydowscy z Polski mieli dokładnie określony wzór Żyda, który miał stać się podstawą ich tożsamości. Uri Awneri, od 1950 roku współwłaściciel izraelskiego tygodnika „Ha-Olam ha-Ze”, pisał, że „hebrajska izraelskość oznaczała młodość, zdecydowanie i bunt; Żyd wygnaniec był stary, ciemiężony i narzekał"23. Ci emigranci żydowscy, którzy nie zgadzali się z syjonistyczną wizją, często wchodzili w konflikt z tym krajem, a syjoniści traktowali ich po prostu jako "konieczne zło”, nieufnie i z pogardą. David Ben Gurion na wszelkie narzekania ze strony niezadowolonych emigrantów odpowiadał: „Można latami mieszkać w namiocie. Ci, którzy nie chcą mieszkać w namiocie, nie powinni byli tu przyjeżdżać"24.

Pierwsi syjonistyczni emigranci żydowscy w liczbie 35 tysięcy zwani "chalucim” (pionierzy) wywodzili się z drugiej emigracji, z lat 1904-1914. Pochodzili z Europy Wschodniej i Środkowej, zwłaszcza z Imperium Rosyjskiego, w skład którego wchodziły w tym okresie również ziemie dawnej Rzeczypospolitej zajęte przez Rosję w wyniku rozbiorów. Kim byli ci pionierzy?

Szesnasto-, siedemnastoletni marzyciele, dawni uczestnicy ruchów rewolucyjnych, zapatrzeni w udającego chłopa hrabiowskiego Lwa Tołstoja, byli bez grosza przy duszy, jedli mało, a jak trzeba było, to głodowali. Nie przeszkadzało im chodzenie na bosaka czy w chłopskiej rubaszce. Po zachodzie słońca i ciężkim dniu fizycznej pracy potrafili godzinami śpiewać, dyskutować i snuć marzenia o nowym Izraelu [...]. Pogardzali należącymi do pokolenia ich rodziców, ortodoksyjnych Ży-

\footnotetext{
${ }^{22}$ T. Segev, Siódmy milion, s. 479-480.

${ }^{23}$ Tamże, s. 263.

${ }^{24}$ Tamże, s. 156.
} 
dów, drobnomieszczańskimi osadnikami żydowskimi, którzy w liczbie pięćdziesięciu tysięcy przybyli do Palestyny w latach 1881-1904 [...]. $\mathrm{Ci}$, kontynuując stare tradycje, ubierali się jak panowie $\mathrm{w}$ koloniach, zatrudniali do ciężkich prac arabskich najemników i wysyłali swoje dzieci do Paryża na studia rolnicze [...]. Wierzyli w nową, zbawczą doktrynę religijną - ciężką pracę fizyczną, która według nich była w stanie dokonać cudu przeistoczenia tradycyjnego Żyda, traktowanego z pogardą w Europie, we wzorcowego, godnego podziwu nowoczesnego człowieka, wyzwolonego z jarzma religii i przynależności do rozwarstwionego społeczeństwa ${ }^{25}$.

Według Martina Lipseta i Petera Pulzera idee socjalizmu i komunizmu zyskały wśród Żydów szczególną popularność, ponieważ były „sposobem na ucieczkę od judaizmu i na asymilację w uniwersalnym świecie nieżydowskim"26. Ci pionierzy mieli poczucie misji, której celem nie było odbudowanie "starego świata" żydowskiego z czasów biblijnych czy powielenie rzeczywistości z diaspory polskiej. To oni wyznaczali ideał nowego Żyda, nowe standardy życia, nowe wartości, nowe cele, nową tożsamość, nowego człowieka. Z pewnością nie chodziło tu o asymilację, którą kojarzono z pogardzanym sposobem życia diaspory, lecz o kreację. Co najwyżej możemy to zjawisko nazwać auto-asymilacją (samo-przystosowaniem) $\mathrm{w}$ ramach określonych przez syjonizm ram. Syjoniści uważali, „że należy stworzyć nowe społeczeństwo, całkiem inne niż to, które cechowało żydowski byt na wygnaniu. Proponowali, by Żydzi powrócili na rolę. Życie miejskie było w ich oczach przejawem społecznej i moralnej degeneracji; powrót do rolnictwa miał doprowadzić do narodzenia się w Palestynie nowego czlowieka" ${ }^{27}$. Narzędziem tej kreacji były kibuce. System kibucowy zakładał, że wszyscy zgodnie najpierw określą, a następnie dostosują się do jednego syjonistycznego wzorca wartości, norm i wrażliwości.

Pionierzy tworzący rzeczywistość kibuców byli ideowcami. Opuszczając europejskie kraje, w tym Polskę,

obiecali sobie, że nikt nie będzie nimi poniewierał. Że odrzucą pamięć czarnych chałatów, zdejmą z głów jarmułki. Sami odetną się

${ }^{25}$ E. Sidi, Izrael, s. 182-183.

${ }^{26}$ Tamże, s. 198. Autorka odwołuje się do książki: D. Prager and J. Telushkin, Why the Jews? The Reason for Antisemitism, New York 2003.

27 T. Segev, Siódmy milion, s. 44-45. 
od korzeni tkwiących głęboko w diasporze, od tradycji ubłoconego, nędznego Szettla, od nieżyciowych obyczajów, mitów i przesądów. Nie będą przestrzegać reguł koszernej kuchni, za to będą pracować w szabat. Nie wybudują synagogi, nie powieszą na drzwiach mezuzy, nie ustawią siedmioramiennych świeczników. Ale biało-niebieska flaga z Gwiazdą Dawida będzie w każdym domu. I karabin, aby mogli się bronić. Nie wypowiedzą też słowa w jidysz, dziwnym narzeczu zapyziałych miasteczek Galicji czy Podlasia, którym mówili ich dziadkowie [...]. Zapomną o dawnych profesjach [...]. To zbyt proste, nie chcą w Izraelu powielać tego, co robili kiedyśs ${ }^{28}$.

Taki był pierwotny plan pionierów, który uległ modyfikacji pod wpływem wydarzeń II wojny światowej. Wola przetrwania połączona z poleganiem na sobie stała się dla nich zasadniczą cechą i nakazem po Holocauście. Sytuacja zmieniła się diametralnie. Do nowej ojczyzny zaczęli przybywać Żydzi nie dlatego, że chcieli, lecz dlatego, że nie mieli innego wyjścia. „Wielu zginęło właśnie dlatego, że nie chcieli wyjechać do Palestyny, gdy mieli taką możliwość. Większość rozproszonych po świecie Żydów, z ocalałymi z Zagłady włącznie, nie przyjechała do Izraela po powstaniu państwa"29. Emigranci ci mieli zupełnie inne nastawienie. Gdyby nie tragedia Zagłady, nigdy by nie opuścili swojej starej ojczyzny. To nie była dla nich „alija” (wzniesienie się), lecz upadek. Miejscowi Żydzi mieli świadomość tej różnicy. Można powiedzieć, że godzili się na przyjazd ocalałych z Zagłady polskich Żydów (i nie tylko polskich), lecz czynili to raczej z konieczności niż z otwartości. Łagodnie mówiąc, ocaleni z Zagłady polscy Żydzi nie byli uznawani przez syjonistów za odpowiedni element budowy państwa żydowskiego, ponieważ wielu z nich nie okazywało radości dla wymogu odrzucenia swojej dotychczasowej żydowskiej kultury i tożsamości w imię postulowanej tożsamości Izraelczyka. Do czasu wojny sześciodniowej w 1967 roku Izraelczycy dystansowali się psychicznie od Holocaustu i losów Żydów europejskich. Odcinano się od tych, którym udało się przeżyć nazistowskie obozy śmierci, gdy przybywali oni do Izraela po wojnie. Nazywano ich w izraelskim slangu „sabon” - „mydło”. „Takie nastawienie było klasycznym wyrazem ideologii syjonistycznej, która uważała Żydów z diaspory za fizycznie i psychicznie słabych oraz pozbawionych kręgosłupa, zasługujących na potępienie" ${ }^{\prime 30}$. Jak stwierdził

${ }_{28}$ P. Smoleński, Izrael, s. 240.

${ }^{29}$ T. Segev, Siódmy milion, s. 406.

${ }^{30}$ B. L. Sherwin, Duchowe dziedzictwo, s. 234. 
Tom Segev: „trudno chyba o lepsze wyrażenie pogardy, jaką rdzenni Izraelczycy czuli wobec ocalałych"31. Bardzo dobrze wyraził ten stan napięcia Arnold Zweig: „A ponieważ palestyńscy Żydzi są słusznie dumni z tego, co istnieje, a my jesteśmy słusznie podenerwowani tym, co nie istnieje, dochodzi do licznych napięć" 32 .

Wszyscy przybywający do Izraela Żydzi byli już wcześniej zakorzenieni w jakiejś kulturze i nie była to kultura izraelska. W Izraelu brakowało im przeszłej kultury. „Bywały chwile skrywanej nostalgii za starym krajem. Zaczęłam lubić tę ciszę i ciemność, powracały do mnie zapachy zimna i śniegu, woń ziemi i słomy, miałam takie sny, jakby za chwilę wszystko miało zacząć się od początku” ${ }^{\prime 33}$. Opłakiwali „nie tylko to, co było, a czego nie ma, lecz przede wszystkim to, co mogło być, a czego nigdy nie będzie" ${ }^{\prime \prime 34}$. Na różne sposoby żydowscy emigranci próbowali zbudować lub choćby ocalić namiastkę tego utraconego świata w Izraelu w swoich domach. W księgarni Edmunda Neusteina w Tel Awiwie przez lata spotykali się polscy Żydzi. „Najważniejsze jednak, że byli tam ludzie, dla których Polska i polskie słowo pisane stanowiły prawdziwą wartość". To nie była zwykła księgarnia. To była namiastka Polski, za którą się tęskniło i nosiło w sercu. „Przychodziło się tam jak do «polskiego domu» na obczyźnie po to, aby pooddychać atmosferą polskości, zapytać o pracę, przeczytać polskie gazety, znaleźć pierwszy Elementarz Mariana Falskiego i książki naukowe pomocne podczas studiów" ${ }^{\prime \prime 3}$. Szewach Weiss, były ambasador Izraela w Polsce, wspomina: „Odkąd zamieszkaliśmy w Izraelu, moi rodzice aż do końca ich życia byli dla mnie Polską. Mieli biblioteczkę polskich książek, czytali polskie gazety i pięknie opowiadali o życiu w dawnej ojczyźnie. Uwielbiali wspominać polskie krajobrazy i polskich sąsiadów"36.

Emigrantom żydowskim często towarzyszyło zdziwienie, zaskoczenie, a nawet rozczarowanie tym, co zastali w Izraelu. Niezwykle trudno było im to zaakceptować. W kraju, gdzie spodziewali się spotkać coś znanego i bliskiego, doświadczyli czegoś nowego i zupełnie obcego. Nie-

${ }^{31}$ T. Segev, Siódmy million, s. 174.

${ }^{32}$ E. L. Freud (red.), The Letters of Siegmund Freud \& Arnold Zweig, London 1970, s. 57.

${ }^{33}$ L. Doron, Spokojne czasy, Warszawa 2010, s. 114.

${ }^{34}$ Taż, Dlaczego nie przyjechataś przed wojnq̨?, Warszawa 2012, s. 20.

${ }^{35}$ E. Sidi, Izrael, s. 240.

36 Sz. Weiss, Ludzie i miejsca, Kraków 2013, s. 12. 
mieccy Żydzi nie chcieli być uczeni. Uważali, że to oni mogą i powinni uczyć innych: „My także chcemy uczestniczyć w przebudowie kultury naszego narodu" - powiedział jeden $z$ ich przedstawicieli ${ }^{37}$. Czasami kpiono z wiary Jeke w wartość formalnej edukacji i wykształcenie zawodowe oraz ze znaczenia, jakie przypisywali jakości pracy. Jiszuw wyżej cenił pracę fizyczną i zdolność do improwizowania. Atakowano Jeke za nadmiernie wysoki standard życia, jaki budowali sobie w Palestynie, sprzeczny z ideologią, która zrównywała obfitość z moralnym zepsuciem. "Jednak im usilniej starano się odciąć Jeke od ich kultury i języka, tym głębsza była ich alienacja"38. David Ben Gurion stwierdził, że niemieccy imigranci „mają równocześnie i kompleks wyższości, i niższości. Kompleks wyższości mówi: «wykształcono nas w kulturze niemieckiej, mamy Kanta i Beethovena, najlepsze powieści, niemiecką filozofię i kulturę [...] A tu wszystko jest wschodnioeuropejskie». Ale istnieje także kompleks niższości. Widzą, że ludzie tu coś zrobili"39.

Wielu nie zdawało sobie wcześniej sprawy, że Żydzi to nie tylko ci, którzy pochodzą z Europy Środkowo-Wschodniej, i nie tylko tacy, jakich znali z Polski. „Zaczęły się też pierwsze ogromne alije Żydów - imigracje do Izraela. My, chłopcy w Hadassim, do tej pory żyliśmy w naszym małym polskim świecie. Myślałem, że cały żydowski naród pochodzi z Polski [...]. Do Izraela przyjechały setki tysięcy Żydów z Afryki Północnej, z Syrii. Wyglądali inaczej, mieli inną kulturę, ale mówili po hebrajsku"40. Jurek (Uzi) Freidkim, emigrant z 1957 roku, przeżył szok kulturowy, gdy

zobaczył wschodnich Żydów z Maroka, o smagłej cerze, stłoczonych pod pokładem i jedzących palcami posiłek prosto z podłogi. Dwie godziny patrzył na nich z góry i nie potrafił przyjąć do wiadomości faktu, że on i oni należą do tego samego narodu żydowskiego, a w nowej ojczyźnie będą tworzyli ten sam naród izraelski. W Izraelu trudno mu było przyzwyczaić się do pustynnego krajobrazu, gorącego, wilgotnego klimatu, odmiennej mentalności i zarozumiałych sabrów przekonanych o wyższości „wspaniałej kultury izraelskiej” nad kulturą polską, którą on uważał za o wiele bardziej rozwiniętą ${ }^{41}$.

\footnotetext{
${ }^{37}$ T. Segev, Siódmy milion, s. 53.

${ }_{38}$ Tamże, s. 56.

39 Tamże, s. 59.

${ }^{40}$ Sz. Weiss, Ludzie i miejsca, s. 15-16.

${ }^{41}$ E. Sidi, Izrael, s. 271-272.
} 
Z kolei Rimonę Weintraub zaskoczyła przede wszystkim:

bolesna metamorfoza mamy, która z elegantki w szpilkach z dnia na dzień przeistoczyła się $\mathrm{w}$ kobietę $\mathrm{w}$ wyświechtanym płaszczu i za dużych, gumowych kaloszach, a także to, że nowa mama zamiast zabrać ją do dużego eleganckiego mieszkania, do jakiego w Gdańsku była przyzwyczajona, wsiadła razem $\mathrm{z}$ nią do brązowego arabskiego autobusu jadącego do miejsca ich nowego pobytu w małej osadzie koło Nazaretu, gdzie czekał na nie azbestowy barak bez lodówki i pralki [...]. Bardzo jej trudno było wtedy zrozumieć, jak to możliwe, że ona i ci ludzie mieszkają w jednym kraju, i co ją łączy z innymi Izraelczykami ${ }^{42}$.

Jeszcze inny emigrant stwierdza:

Wszystko mnie odrzucało: pogoda, brzydkie miasta, piasek, niezrozumiały język, Żydzi z innych kręgów kulturowych, z którymi nie czułem żadnej więzi, jedzenie o smaku, do jakiego nie byłem przyzwyczajony, obcość krajobrazów i kultury... Nie miałem jednak wyboru. Musiałem się do Izraela przyzwyczaić, zaakceptować go i uczynić swoim, jeśli nie dla siebie, to dla moich dzieci, by nikt ich nigdy śmiał wyrzucić z kraju, gdzie zbudowały swój dom. Jestem jak adoptowane dziecko, którego wyrzekli się rodzice ${ }^{43}$.

W podobny sposób wypowiada się Branley Zeicher:

Ja myślałem - wspomina po latach - że Żydzi w Izraelu będą podobni do mnie i mojego sąsiada z Nowego Światu. Nie zdawałem sobie sprawy z tego, że są Żydzi wschodni. Dla mnie kulturowo to byli Arabowie wyznania mojżeszowego. Nic mnie z nimi nie łączyło i to był dla mnie największy szok. Państwo Żydów okazało się prymitywnym krajem lewantyńskim, nie zaś europejskim, jak się spodziewałem. W tamtych czasach "kultura izraelska” to był akordeon i tańce ludowe na bosaka, powszechny brak estetyki ${ }^{44}$.

Z większości wypowiedzi Żydów polskich wynika wprost, że ich spotkanie $\mathrm{z}$ Izraelem zrodziło $\mathrm{w}$ nich poczucie obcości, niekiedy większe od tego, którego doświadczyli poprzednio w Polsce.

\footnotetext{
42 Tamże, s. 272.

43 Tamże, s. 288.

44 Tamże, s. 293.
} 
Do początkowego poczucia obcości dochodziło u emigrantów poczucie rozdarcia. Przyjeżdżając do Izraela, ci ludzie utracili świat, który był dla nich bliski i ważny. Było to o tyle bolesne, że w Europie też czuli się rozdarci. Mieli nadzieję, że żydowski kraj wybawi ich od tej dwuznaczności. Nie zawsze się to udawało. Abraham Rotfarb przybyły z Polski do Izraela w 1948 roku tłumaczy swoją ambiwalencję i zagubienie:

Ja biedna zasymilowana dusza! Jestem Żydem - i jestem Polakiem; a raczej - byłem Żydem, ale ewolucyjnie, pod wpływem otoczenia [...] pod wpływem mowy, kultury i literatury, stałem się Polakiem też. Kocham Polskę. Jej mowa, kultura, a nawet więcej - jej wyzwolenie i heroizm walk niepodległościowych, łechce moje serce, uczucie i entuzjazm. Ale nie kocham tej Polski, która mnie bez żadnych powodów nienawidzi! Która rozrywa mą duszę i serce, która spycha mnie w apatię, w melancholię i ciemną bezcelowość. Nienawidzę tej Polski, która nie tylko że mnie nie chce jako Polaka, a widzi mnie tylko Żydem, ale która jeszcze chce mnie wypędzić z Polski, kraju, gdzie się urodziłem i który mnie wychował. Tej Polski nienawidzę - nienawidzę antysemityzmu. Wam, antysemici, przypisuję swój kompleks niższości i to, że nie wiem, czym jestem - Żydem czy Polakiem! ${ }^{45}$

Niestety w Izraelu tak samo jak w Polsce byli traktowani jako inni i czuli się gorsi. Jedna z emigrantek pisze: „Dlaczego tak się stało, że nie ma dla mnie jakby odpowiedniego miejsca na ziemi? Źle, bardzo źle jest mi w Izraelu, źle również w Polsce"46. Wynikało to z niejednorodności Izraelczyków. Izraelczycy wciąż się zmagają między sobą, a nowy emigrant dodatkowo zmaga się z sobą. Izrael to "tygiel narodowości, religii i kultur [...], kontrasty zamiast się zacierać, jeszcze się bardziej pogłębiły, każda grupa zdaje się odczuwać silną potrzebę znalezienia własnej niszy, wąskiego kręgu podobnych kulturowo ludzi. A wyjście poza ten krąg nadal przypomina wyprawę do cudzoziemskich sąsiadów, obcych, których zna się tylko pobieżnie i traktuje stereotypowo" ${ }^{\prime 4}$. Każda grupa Żydów izraelskich tworzyła własne środowisko, którego broniła. Irena, pracowniczka izraelskiej telewizji opisała ową sytuację następująco:

${ }^{45}$ A. Cała (red.), Ostatnie pokolenie: autobiografie polskiej młodzieży żydowskiej okresu międzywojennego: ze zbioru YIVO Institute for Jewish Research w Nowym Jorku, Warszawa 2003, s. 119.

${ }^{46}$ L. Ulicka, Daniel Stein, ttumacz, Warszawa 2012, s.137.

${ }^{47}$ E. Sidi, Izrael, s. 528. 
Każdy Żyd, który wraca do Izraela, uważa, że wrócił na swoje. To szczera prawda. Tyle, że jej skutki bywają żałosne. Jeśli jestem na swoim, to z tym swoim mogę zrobić, co zechcę. Mogę to zepsuć, zniszczyć, urządzić po swojemu. Wolno mi się rozpychać, odgradzać granicami. Mogę znaczyć terytorium i przeganiać obcych [...]. Liczy się tylko moje zdanie. Każde inne jest fałszywe, błędne. Czasami niewarte nawet zauważenia, niegodne polemiki. A już z pewnością szacunku ${ }^{48}$.

Przybywający do Izraela Żydzi musieli się zmierzyć z każdą z grup izraelskich. Za najbardziej uprzywilejowaną i zasłużoną grupę uznawano sabrów, którzy na wszystkich innych Żydów z diaspory patrzyli z góry i podejrzliwie. Świadczą o tym poniższe słowa: „Znam kilku Izraelczyków, którzy przez wiele lat bardzo niechętnie przyznawali się, że są z diaspory. Sabra jak owoc kaktusa, w środku słodki i soczysty, na zewnątrz odziany w kolczastą skórkę - to dziś najlepsze pochodzenie. Sabra nie płacze, nie prosi, tylko żąda i bierze, co uzna za swoje"49. Można przypuszczać, że to David Ben Gurion nadał sabrom uprzywilejowaną pozycję i wyznaczył przewodnią rolę w kształtowaniu Izraela. „Pokładał on nadzieje w sabrach, urodzonych w Izraelu potomkach rodu pionierów, którzy przekształcą Izrael z europejskiej kolonii w autentyczne azjatyckie państwo, jakkolwiek państwo wyjątkowe" ${ }^{\prime 50}$. Pisarka izraelska Jehudit Hendel w jednym z programów telewizyjnych stwierdziła:

Mówiąc wprost, w tym kraju istniały właściwie dwie rasy ludzi. Jedna rasa to ci, którzy uważali się za bogów. To oni mieli honor i przywilej urodzenia się w Deganii albo w dzielnicy Borochow w Giwataim [...]. Możemy też niewątpliwie powiedzieć, że istniała rasa gorsza. Ludzie, których uważaliśmy za gorszych, mieli jakąś niedoskonałość, jakiś garb, a byli to ludzie, którzy przybyli po wojnie. W szkole uczono mnie, że najbrzydszą, najbardziej godną pogardy rzeczą nie jest wygnanie, ale Żyd, który stamtąd przybywa ${ }^{51}$.

Sabrowie nie byli najlepiej nastawieni do polskich Żydów także dlatego, że ci ostatni nie przejawiali zachwytu nad rzeczywistością Izraela. „Izraelczykom, sabrom, wydawało się, zwłaszcza po wojnie sześciodnio-

${ }^{48}$ P. Smoleński, Izrael, s. 50-51.

49 Tamże, s. 71.

${ }^{50}$ P. Johnson, Historia Żydów, Kraków 1993, s. 581-582.

${ }^{51}$ T. Segev, Siódmy milion, 170. 
wej, że Izrael jest krajem najwspanialszym na świecie, przewyższającym inne pod każdym względem. Polscy emigranci z 1968 byli o wiele bardziej krytyczni"52. Polski emigrant z góry wiedział, że nigdy nie stanie się sabrem, niezależnie od tego, jak bardzo by się starał. Zdaniem Szewacha Weissa proces Eichmanna zmienił nieco nastawienie sabrów do emigrantów z Polski. „Pierwszy raz poczuliśmy się w naszej ojczyźnie jak w domu. Pierwszy raz sabrzy - Żydzi urodzeni w Erec Israel - okazali nam respekt [...]. Wcześniej patrzyli na nas jak na barany, które szły na rzeź" ${ }^{\prime 53}$.

Polscy Żydzi stanowili opozycję nie tylko dla sabrów, którzy usadowili się w Izraelu przez lata lub w tym kraju już się urodzili. „Po przybyciu imigrantów z krajów islamu pojawił się nowy rodzaj tarć społecznych. Nie chodziło już o weteranów przeciwko ocalałym z Zagłady, Sabrów przeciwko ostatkowi, ale o europejskich Żydów przeciwko Żydom orientalnym, Aszkenazyjczyków przeciwko Sefardyjczykom"54. Emigranci z Polski stali się uosobieniem europejskich Aszkenazyjczyków, których nie łączyło $z$ orientalnymi przybyszami prawie nic. W Izraelu słowo „Polani” nie odnosi się jedynie do faktycznego polskiego Żyda, lecz „ma się na myśli również aszkenazi, aszkenazyjczyka, przedstawiciela klasy średniej, zwykle o jasnej skórze, dobrze sytuowanego, mieszkającego w dobrej, czyli europejskiej dzielnicy, dla którego kultura, wykształcenie i wysoki standard w każdej dziedzinie są w życiu priorytetowe ${ }^{\prime \prime 55}$. Charlie Biton - działacz społeczny pochodzenia marokańskiego wybrany do Knesetu z listy komunistycznej stwierdził: „Antysemityzm zrodził się w przemysłowej Europie. W Maroku nie było antysemityzmu. Europejscy Żydzi byli klasą wyzyskiwaczy, a w Izraelu są tacy sami. Ruch syjonistyczny przybył tu i uczynił z tego kraju odgałęzienie Europy"56. Dla polskich Żydów Holocaust był istotnym elementem tożsamości. Sefardyjczykom z trudem przychodziła akceptacja Zagłady jako części własnej historii. Warto podkreślić, że żydowscy emigranci z Europy Środkowej i Wschodniej często uważają się za lepszych od innych, a na pewno od tych "czarnych" z Maroka lub Jemenu. Ci ostatni czują się poniżani i wykorzystywani przez tych pierwszych. Wygłaszane są pretensje

\footnotetext{
${ }^{52}$ E. Sidi, Izrael, s. 294.

${ }^{53}$ Sz. Weiss, Ludzie i miejsca, s. 18.

54 T. Segev, Siódmy milion, s. 176.

${ }^{55}$ E. Sidi, Izrael, s. 248.

56 T. Segev, Siódmy million, s. 371.
} 
i stawiane pytania. „Oni chcą tylko, żebym u nich sprzątała. Chcą się mną wysługiwać. Co mnie obchodzi, że tyle wycierpieli w tej Europie. Dlaczego jest im lepiej i łatwiej? [...] Dlaczego ci Polacy, ci Rosjanie, ci Niemcy tak się wysoko noszą? Dlaczego mamy być ich służącymi? Czy są lepszymi Żydami niż my?"57 W tym wypadku zamiast asymilacji częściej dochodzi do wzajemnej rywalizacji i prób dominacji. Każda z tych grup jest przekonana, że izraelskość powinna odzwierciedlać dokładnie ich żydowskość, a nie innych. Poczucie wyższości poszczególnych grup Żydów w Izraelu wydaje się powszechne. Nawet ci z Gazy uważają się za lepszych od innych i prawdziwych. Głośno twierdzą: „Ludzie, którzy tu jeszcze mieszkają, są inni niż ci w Tel Awiwie, niż bezbożnicy z kibuców. Wierni Bogu, odważni, waleczni, miłują się jak bracia. To Gusz Katif uczyniło ich szlachetniejszymi"58.

Przybyłych do Izraela Żydów czekało jeszcze zderzenie z dwoma stronnictwami:

chilonim, Żydów świeckich, i charedim (bogobojni), które nastawione są zdecydowanie opozycyjnie wobec siebie, mało o sobie wiedzą, nie akceptują swoich odmiennych wyborów dotyczących religii, dziedzictwa narodowego i państwa. W codziennym życiu ich wzajemne kontakty są najaktywniejsze wtedy, gdy spotykają się ze sobą po dwóch stronach ulicy podczas burzliwych demonstracji związanych z walką o prawa cywilne i religijne ${ }^{59}$.

Twórcy państwa żydowskiego marzyli o całkowicie świeckim państwie. Dość szybko okazało się, że religia jest im potrzebna i traktowali ją instrumentalnie.

Prawdą jest, że syjoniści, na ogół niereligijni czy też antyreligijni, przyzywali na pomoc judaizm. Nie mieli innego wyboru. Bez judaizmu, bez idei Żydów jako jednego ludu zjednoczonego wspólną wiarą, syjonizm był niczym, zwykłą szaleńczą sektą. Przyzywali Biblię. Wywodzili z niej wszelkiego rodzaju morały polityczne, retorykę wyborczą i idealistyczne apele do młodzieży. David Ben Gurion wykorzystywał ją jako przewodnik strategii wojskowej. Była to jednak jedynie wschodnioeuropejska wersja żydowskiego Oświecenia. W syjonizmie brak było

${ }^{57}$ P. Smoleński, Izrael, s. 250.

58 Tamże, s. 268.

${ }^{59}$ E. Sidi, Izrael, s. 96. 
miejsca dla Boga właśnie jako Boga. Dla syjonistów judaizm był po prostu wygodnym źródłem siły i kultury narodu ${ }^{60}$.

Syjoniści próbowali rozszerzać swoje wpływy na tożsamość ocalałych z Zagłady europejskich Żydów już w obozach przesiedleńczych. Także przywódcy religijni domagali się tam „wprowadzenia edukacji religijnej, modlitw, publicznego przestrzegania szabatu i koszernego jedzenia w obozach"61. Co ciekawe, religijni Żydzi zmuszeni byli uznać istnienie syjonizmu i ustosunkować się do tej świeckiej idei. „Tak jak syjonizm wykorzystywał judaizm do stworzenia państwa, tak też niektórzy pobożni Żydzi uważali, że narodowy duch syjonizmu można będzie wykorzystać w celu nakłonienia Żydów do powrotu do judaizmu"62. Konflikt między frakcją religijną a laicką wciąż trwa i zmusza emigrantów do opowiedzenia się po jednej lub drugiej stronie. Tymczasem wybór wcale nie jest łatwy i oczywisty. Izrael jest bowiem krajem, który deklaruje się jako świecki z obywatelami, którzy w 70\% nie są religijni. Jednocześnie w żydowskim państwie obowiązują wszystkich prawa i przepisy, które mają charakter całkowicie religijny (np. przepisy prawne dotyczące małżeństwa). Emigrant tego nie rozumie, narzeka, lecz musi akceptować, ponieważ nie ma wyjścia. Bycie Żydem świeckim w Izraelu, jak głosi izraelski dowcip, ,jest jak skakanie z samolotu w szabat. Można skakać, ale nie można otwierać spadochronu"63. Pomijając przedwojennych niereligijnych syjonistów, wielu powojennych polskich Żydów nie było wyznawcami judaizmu, a część z nich była ateistami i komunistami. Próba przystosowania się do nowych warunków niejednokrotnie prowadziła ich do sekularyzacji symboli i obrzędów religijnych. To, co kiedyś tradycyjnie miało znaczenie religijne, w Izraelu nabiera charakteru świeckiego, izraelskiego - nawet szabat. „Wprawdzie kibuc [...] deklarował się jako laicki, jednak tego dnia stoły do kolacji były zawsze nakryte białymi obrusami, a przy wejściu do ogromnej jadalni witały wszystkich artystycznie ułożone kwiaty, przy których stały dwie szabasowe świece oraz chała (specjalne pszenne pieczywo na szabat)" ${ }^{\prime \prime 4}$. Nawet kwestia obrzezania stawała się w Izraelu ogromnym problemem. Przekonuje

\footnotetext{
${ }^{60}$ P. Johnson, Historia Żydów, s. 584.

${ }^{61}$ T. Segev, Siódmy million, s. 133.

${ }^{62}$ P. Johnson, Historia Żydów, s. 584-585.

${ }^{63}$ E. Sidi, Izrael, s. 76.

${ }^{64}$ I. Jaruzelska, Gdy czytam Biblię, s. 57.
} 
nas o tym następujący przykład: Dani Tracz, emigrant z Polski, pochodzący ze zasymilowanej rodziny ateista i antyklerykał, postanowił nie poddawać brit mila, obrzezaniu, swego mającego się właśnie narodzić pierworodnego syna, ponieważ kojarzyło mu się to z "pogańską i prymitywną ceremonią". Pod wpływem środowiska jednak zmienił zdanie i , ,jak wszyscy Żydzi w Izraelu - obrzezał swego syna, a lata później jego syn, świecki Żyd, wnuk komunistów i syn ateisty, uczynił to samo dla swojego potomka"65. Ową niekonsekwencję i dwuznaczność chyba najlepiej opisał Samuel Bergmann:

W judaizmie od niepamiętnych czasów zawsze były dwa nurty ścierające się w pojedynku. Jeden jest izolacjonistyczny, nienawidzi obcych, podtrzymuje kompleks Amaleka i przy każdej okazji podkreśla: pomnij, co ci uczynit. Jest także inny judaizm, który scharakteryzowałbym może słowami: miłuj bliźniego swego jak siebie samego. To judaizm, który modli się: pozwól mi zapomnieć Amaleka, judaizm miłości i przebaczenia. Tu leży klucz do zrozumienia podstawowego podziału $\mathrm{w}$ polityce Izraela: nacjonalistyczny izolacjonizm kontra humanistyczna otwartość6 ${ }^{6}$.

Okazuje się jednak, że niełatwo było także emigrantom, którzy byli religijni. Jeden z nich po latach wyznaje, że "odsuwano się od niego, gardzono nim, gdyż dla wielu Izraelczyków był odrzuconym symbolem: brudnym, krzykliwym Żydem, chałaciarzem, lękliwym człowiekiem z niezmywalnym piętnem diaspory i Holocaustu, wstydliwą antytezą dumnego, silnego Izraelczyka"67.

W Izraelu ludzi dzieli wiele elementów kulturowych. Religia jest tym wymiarem, który wydaje się zasadniczy i najbardziej zapalny poza zewnętrznym zagrożeniem ze strony świata arabskiego. W Izraelu Żydzi religijni i niereligijni żyją obok siebie, tworząc dwa odmienne i odseparowane obszary. Istnieje pewne podobieństwo między Żydami przechodzącymi proces laicyzacji a Żydami przybywającymi do Izraela. Chodzi o drastyczną odmianę losu, wybór innej niż dotychczasowa drogi, zostawienie znanego skrawka dotychczasowej rzeczywistości, tęsknotę za przeszłością. W takiej sytuacji ma się świadomość braku przynależności: nie należy już się do świata przeszłego i nie należy się jeszcze do świata przyszłego.

\footnotetext{
${ }^{65}$ E. Sidi, Izrael, s. 75.

66 S. H. Bergmann, Tagebucher Briefe, 1948-1975, t. 2, Konigstein 1985, s. 415.

${ }^{67}$ P. Smoleński, Izrael, s. 45.
} 
Izrael z założenia miał być państwem świeckim. Syjonistom nie do końca się to udało. Niemniej jednak wciąż dostrzegalne są przejawy sekularyzacji tradycyjnej kultury żydowskiej w żydowskim państwie, co stanowi zarzewie wewnętrznych konfliktów społecznych. Widać to szczególnie w kulturze codziennej i popularnej.

Historia Żydów w diasporze pokazuje, że strój miał dla nich niezwykle istotne znaczenie. Nie był związany z modą, lecz stanowił element tożsamości żydowskiej, który odróżniał wyznawców judaizmu od gojów. Ubiór był zewnętrzną manifestacją żydowskości w diasporze. Ci Żydzi, którzy pod wpływem oświecenia żydowskiego decydowali się na asymilację, zaczynali od zmiany sposobu ubierania się, aby w ten sposób upodobnić się do tych, wśród których żyli. Dążąc do unifikacji z innymi, chcieli wyglądać jak inni. Przybywający do Izraela Żydzi nie zmieniali swoich przyzwyczajeń. W spotkaniu z miejscowymi Żydami (sabrami i kibucnikami) zarówno zasymilowani, jak i religijni emigranci byli zaskoczeni i zdziwieni ich wyglądem. Tym pierwszym nie pasował brak elegancji, tych drugich drażnił brak skromności i tradycji. „Byli inni. Nosili buty odsłaniające palce i paznokcie, krótkie spodnie i podkoszulki - bez koszul i krawatów; głowy przykrywali płóciennymi czapkami, zarówno dziewczyny, jak i chłopcy; nikt nie miał trwałej ani nie używał lakieru do włosów, nie było jarmułek ani kapeluszy"68. Polscy Żydzi nie chcieli tak wyglądać.

W Izraelu paradoksalnie wygląd ma znaczenie, a sposób ubierania się jest świadomym wyrazem tożsamości poszczególnego Izraelczyka. Tutaj strój nie służy upodobnieniu się, lecz odróżnieniu się jednych Żydów od drugich. W tym względzie asymilacja przybywających do Izraela Żydów nie polega na przystosowaniu się do mody, klimatu, statusu społecznego. Ważne tu są inne kryteria. Prowadzi to niekiedy do paradoksu, jakim okazuje się noszenie futrzanej czapy w czterdziestostopniowym upale. "Charedim pozostali wierni europejskiej modzie mimo odmiennego klimatu kraju, w którym mieszkają. Hołdują bowiem przekonaniu, że dla zachowania tożsamości żydowskiej istotne jest nie tylko to, aby zapewnić ciągłość historii i tradycji żydowskiej, ale i nie zmieniać języka, imion czy ubioru" ${ }^{\prime 69}$. Przestarzały, niepraktyczny, nieprzystosowany do klimatu sposób ubierania się charedim bywa przedmiotem żartów. Ale oni sami traktują to bardzo poważnie. Dla nich kipa to znak rozpo-

${ }^{68}$ L. Doron, Dlaczego nie przyjechataś, s. 69.

${ }^{69}$ E. Sidi, Izrael, s. 115. 
znawczy odróżniający ich od mniej religijnych Żydów, który potwierdza przynależność do określonego odłamu religijnego, uniform, w którym zakodowane są konkretne informacje dotyczące stanu cywilnego (żonaty, kawaler, mężatka, panna), miejsca zamieszkania (Jerozolima czy inne miejscowości), funkcji religijnej (rabin, uczeń), pochodzenia etnicznego (aszkenazyjczyk, sefardyjczyk). Polscy chasydzi odróżniają się od innych Żydów i chcą tego. Według nich strój chroni przed pokusami świeckiego świata i oddziela od niego dwustronną barierą. Dodatkowo szczegóły stroju pozwalają im różnić się między sobą.

W Izraelu po sposobie ubierania się trudno określić status materialny człowieka, ale za to wiele można się dowiedzieć o jego przynależności do religijnego bądź świeckiego świata żydowskiego lub muzułmańskiego. W żydowskim kraju przybyły emigrant musi wiedzieć, jak się ubierać. To nie jest zwykła sprawa mody i estetyki, lecz określenia swojej tożsamości. Kibucnikom wystarczy prosty, luźny strój i skórzane sandały lub klapki. W miastach natomiast Żydzi świeccy starają się nie odbiegać od globalnych trendów mody. Tymczasem masowo noszone przez Izraelczyków i odpowiednie na każdą okazję dżinsy są całkowicie niedopuszczalnym ubiorem dla Żydów religijnych.

Mężczyźni na co dzień zdecydowanie unikają, poza koniecznością wynikającą z zajmowanego stanowiska, marynarek, krawatów i eleganckich koszul, o ile nie są mitnagedami i naśladującymi ich w ubiorze ultraortodoksyjnymi sefardyjczykami, ubranymi w każdy dzień w garnitury i białe koszule ze starannie zawiązanymi krawatami. Izraelki niechętnie noszą sukienki czy spódnice za kolana, które mogłyby fałszywie sugerować ich przynależność do świata religijnego. Na przekór Żydówkom ultraortodoksyjnym z ogolonymi głowami lub krótkimi włosami, skrupulatnie chowanymi pod chustkami czy perukami, często zapuszczają długie włosy (zwykle gęste, kręcone lub falujące) i noszą je rozpuszczone $\mathrm{e}^{70}$.

Nawet jeśli zasymilowany polski Żyd, który przybył do Izraela, zdecydował się na noszenie kipy jako niereligijnego symbolu tożsamości izraelskiej, nie raz wpadł w pułapkę. Tu bowiem liczy się każdy szczegół: wielkość, kolor, wzór. Przybywający do Izraela emigrant, tak jak przeciętny turysta, na ogół tego nie wie. To wszystko ma swoją konotację. W społeczności sefardyjskich litwaków wstążka, którą wykańcza się czar-

70 Tamże, s. 112. 
ne kipy, świadczy o stopniu religijności. „Kto chodzi z kipą bez wstążki, ten chodzi do kina bez kipy"71. To popularne w Izraelu porzekadło przestrzega przed zbytnią swobodą i dowolnością w ubieraniu. Polscy Żydzi, tak jak inni, na ogół trzymają się w kwestii ubioru przywiezionej ze swojego kraju tradycji. Wydaje się, że asymilacja w tym zakresie, rozumiana jako upodobnienie się i przystosowanie, nie ma szans. Do kogo bowiem ma się upodobnić i przystosować emigrant z Polski?

Podobny problem dotyczy też spożywania posiłków. Mówi się, że stół łączy ludzi. W tradycji żydowskiej jednak stół zbliżał, ale i oddalał. Nie chodzi tu jedynie o problem koszerności, lecz o różnice kulturowe i obyczajowe związane z tym, co się je i jak się je. Aby lepiej zrozumieć ten problem, należy spotkać się z sefardyjczykami i aszkenazyjczykami przy jednym stole. Opisuje to poniższa relacja:

W domu moich znajomych, Żydów z Polski, na pytanie, czy chcesz coś zjeść, przyjęte jest odpowiadać: „Nie, nie jestem głodny”. A po głębokim namyśle dodawać: „Może jednak szklankę wody?”. U mamy mojej przyjaciółki z Maroka nikt nie pyta, czy ktoś jest głodny. Gości od razu sadza się za stół i częstuje obfitym obiadem, spożywanym wraz z liczną rodziną gospodarzy, sąsiadami, bliższymi i dalszymi krewnymi. W domu aszkenazyjczyków przebojem stołu jest gefilte fisz (jidysz), ryba faszerowana [...]. W domu sefardyjskim gwiazdą stołu jest rybna potrawa zwana chramie [...]. Aszkenazyjska pani domu wystawia na stół bogatą zastawę, świeczki, kwiaty i zaledwie kilka, tych samych co zawsze, potraw. Broń Boże, nie za dużo, by się nie zmarnowało. Goście zamiast rozmawiać - celebrują jedzenie i słuchają koncertu. Stół sefardyjskiej gospodyni ugina się od rozmaitego rodzaju kolorowych sałatek, zwykle ostro przyprawionych, kilku gatunków mięs, ryb oraz obfitości rozmaitych kolorowych dodatków. Nieważne, czy potrawy stać będą w garnku na stole lub zostaną wyłożone na papierowe talerze ${ }^{72}$.

Jak się okazuje, potrawy polskich Żydów nie tylko wpisały się w polską tradycję kulinarną po dziś dzień, lecz są także ważnym składnikiem kuchni izraelskiej. Zachodzi tu sytuacja, w której nie porzuca się swojej dawnej tradycji, a jedynie ubogaca ją nowymi, zastanymi elementami.

${ }^{71}$ Tamże, s. 116.

72 Tamże, s. 27. 
Zasygnalizowane problemy kulturowe Żydów w Izraelu, w których widoczne są przejawy sekularyzacji, pokazują, że punktem wyjścia do ich zrozumienia jest określona tożsamość kulturowa, zarówno jednostkowa, jak i społeczna ${ }^{73}$. Karol Jaron Beker uważa swój przyjazd do Izraela za pozytywne wydarzenie, które wzbogaciło go o nową tożsamość bez potrzeby rezygnacji ze starej. Mówi się o nim: "człowiek o polskim sercu, rosyjskiej duszy z żydowskim rozumem"74. Według niego "człowiek może mieć kilka tożsamości kulturowych, jeśli jest otwarty na świat i nie odrzuca przedemigracyjnych źródeł kultury, tylko buduje swoją nową tożsamość, dodając je do poprzedniej"75. Kluczowe wydają się słowa Bekera:

Kiedy byłem młodzieńcem, musiałem wybierać między byciem Żydem a Polakiem [...] a właściwie nie miałem wyboru, bo rodzice wyjeżdżali i ja, jako niepełnoletni, musiałem wyemigrować, choć tego nie chciałem, i stać się Żydem i Izraelczykiem subiektywnie, to znaczy świadomie (obiektywnie urodziłem się do mego żydowskiego losu od samego początku, na Syberii, gdzie podczas wojny znalazła się moja polsko-żydowska rodzina), choć na całe życie zostałem sformatowany kulturowo na Polaka [...]. Wrastając w hebrajską kulturę, nie chciałem w żadnym wypadku zrezygnować, jako człowiek, z moich poprzednich źródeł tożsamości. I tak się stało, że stając się Izraelczykiem, kontynuowałem bycie Polakiem i nawet trochę Rosjaninem, bo i tej kultury łyknąłem niemało. Może te moje potrójne kulturowe przywiązania mają wiele luk, ale bez zbytniej pychy mogę powiedzieć, że mi z tym dobrze, bo moje spojrzenie na świat jest bardziej panoramiczne, niż gdybym wybrał obsesyjnie tylko jedną tożsamość. Nie mogłem jednak zignorować faktu, że jestem nie jakimś tam Żydem czy tylko Izraelczykiem, ale jestem polskim Żydem i jako polski Żyd także Polakiem. Moja kultura jest częścią polskiej kultury, bo Żydzi polscy byli nie tylko jej odbiorcami, oni ją aktywnie tworzyli ${ }^{76}$.

Dla jednych Izraelczyków bycie Żydem oznacza bycie wyznawcą judaizmu, dla innych wprost przeciwnie, religia jest nie tylko niekoniecznym, ale wręcz niepożądanym elementem tożsamości. W Izraelu chodzi przede wszystkim o zatarcie „inności” poszczególnych grup Żydów,

${ }^{73} \mathrm{O}$ tożsamości zbiorowej i kulturowej pisał S. Hall, Cultural Identity and Diaspora, w: N. Mirzoff (red.), Diaspora and Visual Culture, London-New York 2000, s. 21-31. On też wprowadził pojęcie tożsamości diasporycznej.

${ }^{74}$ E. Sidi, Izrael, s. 285.

75 Tamże.

76 Tamże, s. 285-286. 
którzy przybywają z różnych obszarów i kręgów kulturowych, aby $\mathrm{w}$ ten sposób osiągnąć unifikację obywatelską. Religia jako historyczny i sprawdzony przecież czynnik utrzymujący przez wieki jedność Żydów została programowo i skutecznie odrzucona. Haarscher zwrócił uwagę, że w poszczególnych krajach uwidacznia się dylemat wyrażony w pytaniu, czy gwarantem więzi społecznej ma być religia, czy "coś innego"77. Analiza rzeczywistości kulturowej w Izraelu ujawnia, że paradygmatem izraelskości nie jest religia. Być może rację ma Sherwin, który wskazuje na Holocaust jako na "coś innego”. „Przed Holocaustem najwyższą żydowską wartością było ustrzeżenie, uwiecznienie judaizmu. Od czasu Holocaustu społeczność żydowska eksponuje jako podstawową wartość przetrwanie narodu żydowskiego [...]. W mojej opinii ta zmiana w żydowskiej hierarchii wartości jest zrozumiała, ale ostatecznie okaże się błędna. Judaizm stanowi raison d'etre żydowskiej egzystencji. Przetrwanie Żydów bez tożsamości żydowskiej jest ostatecznie bezsensowne" ${ }^{\prime 78}$. Wydaje się, że kultura izraelska pozbawiona istotnych elementów „żydowskości" (w tym religii żydowskiej) traci swój historyczny i egzystencjalny wymiar, który przez wieki decydował o tym, że była ona wyjątkowa i fundamentalna dla każdego Żyda.

Streszczenie. Przez całe tysiąclecia kultura żydowska miała charakter wybitnie religijny, co decydowało o jej wyjątkowości i specyfice. Można ją nazwać kulturą judaistyczną. Jednak od czasów oświecenia żydowskiego (Haskali), w wyniku procesów asymilacyjnych, pojawiły się w niej elementy, które zrywały z ciągłością historyczną, wyznaczając nowe kryteria tożsamości żydowskiej. Judaizm rozumiany jako religia przestał być koniecznym wyznacznikiem żydowskości. Syjonizm, stojący u podstaw powstania państwa Izrael, programowo dążył do stworzenia „nowego człowieka", którego miała określić świecka kultura. W założeniach nie chodziło ani o nawiązanie do biblijnego Izraela, ani do fenomenu diaspory. Przeciwnie, przeszłość z całym swym bagażem miała zostać porzucona. Syjonizm dążył do zbudowania przyszłości w oparciu o nowe paradygmaty. Nie wszystkie postulaty syjonizmu się spełniły. Współczesny Izrael stał się sceną nie tylko walki z zewnętrznym wrogiem (świat arabski), ale także wewnętrznej walki o charakter państwa. Celem artykułu jest próba scharakteryzowania kultury izraelskiej i ukazanie przejawów zeświecczenia tradycyjnej kultury żydowskiej w państwie żydowskim. Kluczowe bowiem pytanie brzmi: czy i w jakim sensie izraelska kultura ma charakter żydowski?

Słowa kluczowe: Żydzi; kultura żydowska; sekularyzacja; Izrael.

77 G. Haarscher, Laickość, Warszawa 2004, s. 89.

78 B. L. Sherwin, Duchowe dziedzictwo, s. 68. 
Summary: The Characteristics of Jewish Culture in Israel as Expressed by its Secularisation. Throughout millennia, Jewish culture was imbued with an inherent religious component, which determined its exceptional nature and specificity. Hence one may venture to call it a Judaist culture. However, with the onset of the Jewish renaissance (the Haskalah) and in the wake of assimilation processes there appeared elements, which disrupted historical continuity, establishing new criteria of Jewish identity. Judaism understood as religion ceased to be a necessary attribute of Jewishness. Zionism, which laid the foundation of the Israeli state, strove by default to forge a "new man", who was to be determined by secular culture. Its fundamental premises did not draw upon the Biblical Israel or the phenomenon of the Diaspora. On the contrary, the past and its burdens were to be abandoned, as Zionism aspired to create a future based on new paradigms. Yet not all postulates of Zionism came true. Contemporary Israel became both a territory where external foe is fought (the Arab world) and an arena where internal struggle for the nature of the state is taking place. The paper therefore attempts to draw a characterization of Israeli culture and demonstrate the manifestations of secularization to which traditional Jewish culture has been subject in the Jewish state. This is because one is confronted with the fundamental question, namely whether and in what sense Israeli culture is Jewish in nature?

Keywords: Jews; Jewish culture; secularization; Israel. 
